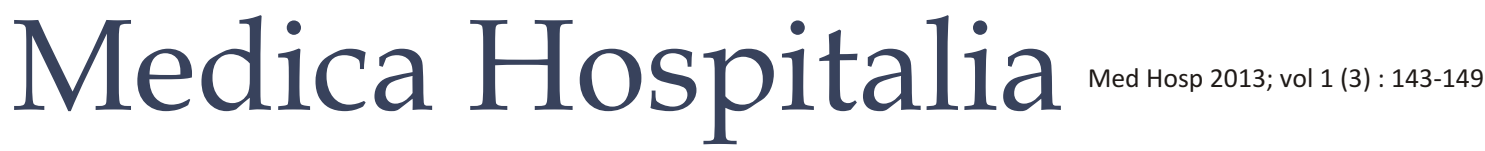

Review Article

Current Concept

\section{Tromboemboli Vena pada Kanker}

\author{
C. Suharti \\ Divisi Hematologi-Medical Onkologi, Departemen Penyakit Dalam/RSUP Dr. Kariadi Semarang Indonesia
}

\begin{abstract}
Abstrak
Trombosis merupakan komplikasi yang sering terjadi pada penderita kanker, angka kejadiannya makin meningkat, dan merupakan penyebab kematian kedua pada penderita dengan kanker. Trombosis pada kanker mempunyai angka kekambuhan dan risiko perdarahan yang tinggi, dan memerlukan pengobatan dengan antikoagulan jangka panjang.

Patogenesis trombosis pada kanker meliputi beberapa mekanisme yang saling berhubungan termasuk antara lain faktor jaringan yang berasal dari tumor dan peranan trombosit. Faktor jaringan diekspresikan oleh sel tumor yang diinduksi oleh pengaktifan onkogen, inaktivasi gen yang menekan tumor, serta berbagai mediator termasukantara lain tumor necrosis factor- $\alpha$, interleukin $-1 \beta$, ligan $C$, trombin and vascular endothelial growth factor. Selain itu juga prokoagulan kanker, yakni suatu protease sistein yang hanya didapatkan pada sel kanker dan jaringan amnion. Faktor ekstrinsik seperti pemberian kemoterapi, agen terapi target seperti bevacizumab, thalidomide, lenalidomide, sunitinib dan sorafenib, juga sering menimbulkan kejadian trombosis.

Pencegahan dan terapi yang efektif untuk tromboemboli vena dapat menurunkan angka morbiditas dan memperpanjang usia. Heparin berat molekul rendah merupakan pilihan yang efektif dan aman untuk pencegahan maupun terapi tromboemboli vena, dibanding unfractionated heparin and antagonis vitamin K. Saat ini telah terdapat panduan baru untuk pencegahan maupun terapi, yang direkomendasikan bagi penderita kanker yang dirawat di rumah sakit maupun penderita kanker yang akan menjalani tindakan bedah mayor.
\end{abstract}

\section{Cancer-associated Thromboembolism}

Abstract

Cancer-associated thrombosis is a common complication seen in oncology patients, and its incidence is increasing. Thromboembolism is the second most common cause of death in cancer patients. Cancer- associated venous thromboemblism is associated with high rate of recurrence, increased risk of bleeding, and a requirement for long-term anticoagulation.

The mechanisms of cancer-associated thrombosis involves several complex interdependent mechanisms including emerging roles for tumor-derived tissue factor and platelets. Tissue factor is expressed by malignant cells, and is induced by activation of oncogenes, inactivation of tumor suppressor genes and by various mediators including tumor necrosis factor- $\alpha$, interleukin- $1 \beta$, CD40 ligand, thrombin and vascular endothelial growth factor. Cancer procoagulant is a cysteine protease found only on malignant cells and in amniotic tissue. Extrinsic factors such chemotherapy administration, newer targeted therapy agents such as bevacizumab, thalidomide, lenalidomide, sunitinib and sorafenib are associated with thrombotic events.

Effective prophylaxis and treatment of venous thromboembolism reduced morbidity and increased survival. Low - molecular-weight heparin is preferred as an effective and save means for prophylaxis and treatment of venous thromboembolism. It has largely replaced unfractionated heparin and vitamin $\mathrm{K}$ antagonist. New guidelines for prophylaxis and treatment are now available and prophylaxis are recommended in hospitalized cancer patients and patients undergoing major surgery.

\section{PENDAHULUAN}

Tromboemboli vena (TEV), termasuk didalamnya trombosis vena dalam (TVD) dan emboli paru (EP), bersama dengan trombosis arteri, yang meliputi stroke dan infark jantung, merupakan komplikasi yang sering dialami penderita kanker. Angka kejadian TEV pada kanker makin meningkat, dan merupakan penyebab kematian ke dua pada kanker. Lebih lanjut, TEV pada kanker mempunyai angka kekambuhan yang tinggi, risiko perdarahan yang meningkat dan memerlukan terapi dengan antikoagulan dalam jangka panjang. ${ }^{1}$

Patofisiologi terjadinya kondisi hiperkoagulasi pada kanker bersifat kompleks, melibatkan berbagai mekanisme yang saling berhubungan, termasuk faktor jaringan yang berasal dari tumor dan trombosit. Identifikasi faktor risiko untuk TEV pada penderita dengan risiko tinggi, serta penatalaksanaan komplikasi 
TEV bilamana timbul selama perjalanan penyakit kanker atau pada saat penggunaan obat anti kanker seperti kemoterapi, terapi hormon, obat golongan antiangiogenesis dan agen imunomodulator sangatlah penting.

Pemahaman yang baik tentang epidemiologi, patofisiologi TEV dan faktor risiko pada penderita kanker merupakan inti dari pencegahan dan penatalaksanaan komplikasi serius ini pada penderita kanker, guna menurunkan angka morbiditas, meningkatkan kualitas hidup, serta meningkatkan ketahanan hidup penderita kanker.

\section{EPIDEMIOLOGI}

Hubungan antara kanker dan trombosis pertama kali diutarakan oleh Armand Trousseau pada tahun 1965 (1801-1867). ${ }^{2}$ Sejak itu, banyak studi tentang hubungan antara trombosis dan kanker dilakukan, dan didapatkan bukti adanya peningkatan risiko trombosis pada beberapa bulan setelah diagnosis kanker ditegakkan dan pada kondisi dimana telah terjadi penyebaran jauh dari kanker.

Angka kejadian trombosis pada kanker bervariasi sangat luas akibat populasi yang amat heterogen dan sulitnya melakukan studi dengan skala besar. Berdasarkan data studi prospektif di Amerika (US), angka kejadian setiap tahun untuk TVD dan EP pada populasi umum sebesar $0,1 \%,{ }^{3}$ sementara untuk trombosis pada populasi kanker diperkirakan sebesar 0,5\% ${ }^{4,5}$ Prevalensi trombosis akibat kanker diperkirakan lebih rendah dari sesungguhnya lebih dari 10 kali lipat, mengingat data dari studi autopsi pada penderita kanker menunjukkan angka kejadian TEV yang jauh lebih tinggi. ${ }^{6}$ Dari suatu studi populasi skala besar didapatkan sebanyak $20 \%$ kasus baru TEV mempunyai penyakit dasar kanker, $26 \%$ lainnya bersifat idiopatik TEV. ${ }^{3}$

\section{FAKTOR RISIKO}

Risiko TEV untuk berbagai kanker telah diketahui, yang meliputi limfoma non-Hodgkin, kanker usus besar, ovarium, paru, dan payudara. Kanker padat seperti kanker pankreas, ovarium dan kanker otak dianggap mempunyai risiko yang jauh lebih besar untuk terjadi TEV dibanding keganasan hematologi. Namun, beberapa studi baru menganggap bahwa angka kejadian TEV pada keganasan hematologi sama seperti pada kanker padat. $^{3}$

Studi prospektif menunjukkan bahwa TEV mempunyai risiko yang lebih tinggi untuk terjadi komplikasi buruk pada penderita dengan kanker termasuk terjadinya kekambuhan TEV, komplikasi perdarahan sewaktu mendapat terapi antikoagulan, meningkatkan mortalitas baik jangka pendek maupun jangka panjang. ${ }^{7,8}$ Faktor risiko yang potensial untuk terjadi TEV pada penderita kanker dapat dikategorikan atas faktor yang berhubungan dengan penderita, penyakit kanker dan pengobatan kanker itu sendiri. Usia lanjut, jenis kelamin wanita, ras Amerika-Afrika dan mutasi protrombotik merupakan faktor risiko untuk TEV. ${ }^{9}$ Lokasi kanker primer merupakan salah satu faktor risiko yang paling kuat untuk TEV, dimana angka tertinggi didapatkan pada penderita dengan kanker otak, pankreas, gaster, ginjal, ovarium, paru dan limfoma. ${ }^{9}$ Laporan dari suatu studi yang berbasis populasi menunjukkan bahwa risiko tertinggi TEV pada 3 bulan pertama setelah diagnosis kanker (OR 53,5, 95\% CI $8,6-334,3) .^{10}$

Obat kanker tertentu dapat meningkatkan risiko trombosis. Thalidomide dan lenalidomide adalah obat golongan imunomodulator yang mempunyai efek anti angiogenik melalui blokade basic fibroblast growth factor dan VEGF (vascular endothelial growth factor) dapat meningkatkan risiko trombosis bila dikombinasikan steroid, doxorubicin, dan agen kemoterapi lain untuk pengobatan mieloma. Bevacizumab, suatu antibodi monoklonal untuk melawan molekul pro-angiogenik VEGF (digunakan untuk pengobatan beberapa tumor padat) telah dihubungkan dengan peningkatan risiko tromboemboli arteri, sedangkan hubungan antara bevacizumab dengan TEV tidak jelas. Angiogenesis adalah suatu proses proliferasi pembuluh darah baru yang mempunyai peran dalam pertumbuhan dan metastasis kanker. Sunitinib dan sorafenib, suatu agen antiangiogenesis, dapat meningkatkan risiko trombosis arteri (RR 3,03, 95\% CI 1,25-7,37). Agen stimulasi eritropoesis dan transfusi darah juga meningkatkan risiko TEV.

Penderita kanker yang menjalani tindakan bedah mempunyai risiko dua kali lipat dibanding penderita bukan kanker. Beberapa studi menunjukkan lamanya waktu di kamar bedah, lamanya dalam anestesi, dan tindakan re-eksplorasi meningkatkan risiko TEV pada penderita kanker. Penggunaan kateter vena sentral (CVC, Central Venous Catheters) memudahkan penatalaksanaan penderita kanker dalam hal pemberian kemoterapi, nutrisi parenteral, antibiotik dll. Namun, penggunaan CVC sering diikuti komplikasi trombosis (CAT, catheter associated thrombosis). Penderita yang mengalami CAT mengeluh nyeri, adanya pembengkakan, parestesi, gambaran vena yang jelas sepanjang lengan dan bahu. Namun beberapa penderita kadang tidak menunjukkan gejala.

Akhir-akhir ini telah dapat didentifikasi suatu biomarker baru yang bersifat prediktif untuk TEV pada penderita kanker. Suatu studi observasional menunjukkan bahwa hitung trombosit sebelum kemoterapi $\geq 350.000 / \mathrm{mm}^{3}$ dan peningkatan hitung leukosit $>11.000 / \mathrm{mm}^{3}$ berhubungan secara independen dengan risiko TEV. ${ }^{11}$ Beberapa biomarker lain seperti ekspresi faktor jaringan yang tinggi pada sel tumor dan 


\begin{tabular}{|c|c|c|}
\hline & & Faktor \\
\hline \multirow[t]{3}{*}{ Faktor risiko klinik } & Faktor berhubungan dengan pasien & $\begin{array}{l}\text { - Usia }>60 \text { tahun } \\
\text { - Jenis kelamin } \\
\text { - Ras } \\
\text { - Episode trombosis sebelumnya } \\
\text { - Obesitas: } \mathrm{BMI} \geq 35 \mathrm{~kg} / \mathrm{m}^{2} \\
\text { - Kondisi komorbid medik kronik } \\
\text { - Mutasi protrombotik yang diturunkan }\end{array}$ \\
\hline & $\begin{array}{l}\text { Faktor berhubungan dengan } \\
\text { penyakit (kanker) }\end{array}$ & $\begin{array}{l}\text { - Jenis tumor } \\
\text { - Kanker stadium lanjut } \\
\text { - Periode awal sejak diagnosis kanker ditegakkan }\end{array}$ \\
\hline & $\begin{array}{l}\text { Faktor yang berhubungan dengan } \\
\text { pengobatan kanker }\end{array}$ & $\begin{array}{l}\text { - Kemoterapi } \\
\text { - Agen antiangiogenik dan imunomodulator } \\
\text { - Penggunaan faktor pertumbuhan hemopoetik } \\
\text { - Tindakan bedah } \\
\text { - Indwelling central venous catheter } \\
\text { - Radiasi } \\
\text { - Terapi hormon }\end{array}$ \\
\hline Biomarker & Biomarker & $\begin{array}{l}\text { - Hitung leukosit }>11.000 / \mathrm{mm}^{3} \\
\text { - Hitung trombosit }>350.000 / \mathrm{mm}^{3} \\
\text { - D-dimer } \\
\text { - F. VIII, Fragmen protrombin, Faktor jaringan } \\
\text { - P-selectin yang larut } \\
\text { - C-reactive protein }\end{array}$ \\
\hline
\end{tabular}

\section{TABEL 2}

\section{Model prediktif untuk TEV yang berhubungan dengan kemoterapi"}

\section{Karakteristik Pasien}

\section{Skor Risiko}

Lokasi kanker

- Risiko sangat tinggi (lambung, pankreas)

2

- Risiko tinggi (paru, limfoma, ginekologi, kandung kencing, testis)

Hitung trombosit prakemoterapi $>350.000 / \mathrm{mm}^{3}$

Kadar hemoglobin $10 \mathrm{~g} / \mathrm{dl}$ atau pemakaian eritropoietin

Hitung leukosit prakemoterapi lebih dari $11.000 / \mathrm{mm}^{3}$

Massa indeks tubuh $35 \mathrm{~kg} / \mathrm{m}^{2}$ atau lebih

Risiko rendah : skor 0

Risiko menengah : skor 1-2

Risiko tinggi : skor $\geq 3$

meningkatnya kadar biomarker dalam sirkulasi seperti faktor jaringan, P-selectin yang larut, D-dimer dan C-reactive protein telah dihubungkan dengan risiko TEV pada kanker. ${ }^{12}$

\section{SISTEM SKOR UNTUK PENILAIAN RISIKO TEV PADA PENDERITA KANKER}

Pada penderita kanker, stratifikasi risiko merupakan proses yang dinamik tergantung jenis dan stadium 


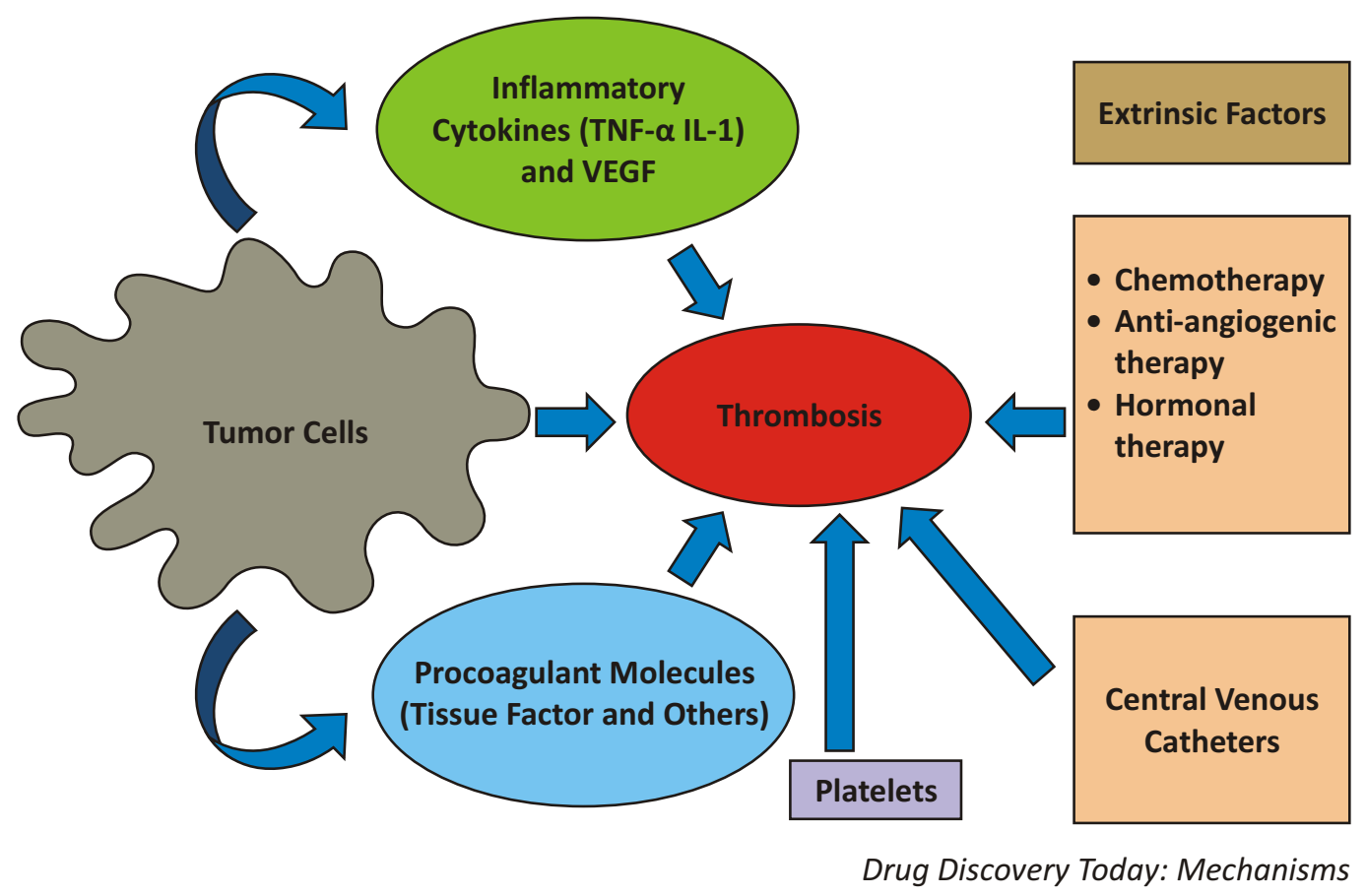

Gambar 1. Mekanisme potensial trombosis pada kanker ${ }^{1}$

kanker, kemampuan penderita beraktifitas (status performance) terapi spesifik kanker maupun terapi suportif. Khorana AA dkk telah menyusun suatu model yang sederhana untuk prediksi TEV pada kanker yang berhubungan dengan kemoterapi dengan menggunakan variabel dasar klinik dan laboratorik (Tabel 2). ${ }^{11}$

\section{MEKANISME TROMBOSIS PADA KANKER}

Patofisiologi trombosis pada kanker belum sepenuhnya dipahami. Kondisi hiperkoagulabel pada kanker melibatkan mekanisme yang saling berhubungan dan kompleks (Gambar 1.) Peran kunci patofisiologi dimainkan oleh (i) faktor jaringan, (ii) sitokin proinflamasi, dan (iii) trombosit.

Faktor jaringan. Faktor jaringan terdiri atas glikoprotein transmembran, berperan sebagai kunci inisiator koagulasi fisiologik, diekspresikan oleh berbagai jenis sel kanker, termasuk kanker padat maupun sel blas leukemia, sel makrofag yang berhubungan dengan kanker dan sel endotel. Pada pembuluh darah normal faktor jaringan tidak diekspresikan, kecuali bila diinduksi oleh sitokin proinflamasi seperti interleukin (IL)-1 $\beta$ dan TNF (tumor necrosis factor)-a atau oleh liposakarida bakteri.

Ekspresi faktor jaringan dari berbagai jenis kanker diinduksi oleh onkogen yang diaktifkan atau gen supresi tumor yang dinonaktifkan. ${ }^{13}$ Faktor jaringan juga diinduksi oleh berbagai mediator termasuk TNF- $\alpha$, IL-1 $\beta$, ligan CD40, trombin, LDL yang teroksidasi, dan
VEGF. ${ }^{14}$ Pada penderita kanker faktor jaringan dapat dideteksi di sirkulasi darah. Faktor jaringan yang bersirkulasi dalam darah menyatu dengan mikropartikel yang berasal dari sel endotel, sel otot polos pembuluh darah, leukosit atau trombosit. Ekspresi berlebihan faktor jaringan pada sel tumor dan peningkatan kadar faktor jaringan dalam darah menyebabkan kondisi hiperkoagulabel.

Suatu studi yang dilakukan oleh Kakkar dkk menunjukkan bahwa kadar faktor jaringan dalam plasma, faktor VIIa, faktor XIIa, kompleks trombinantitrombin, dan fragmen protrombin meningkat pada penderita dengan kanker dibanding kontrol. Faktor jaringan dan faktor VIIa yang keduanya tinggi secara bermakna, menunjukkan pengaktifan secara signifikan dari jalur ekstrinsik. ${ }^{15}$ Di pihak lain, kadar faktor XIIa hanya meningkat sangat sedikit, membuktikan bahwa jalur intrinsik tidak terlibat secara signifikan untuk terjadinya kondisi hiperkoaguabel pada penderita kanker. ${ }^{16}$

Sitokin proinflamasi. Sel tumor juga melepas sitokin proinflamasi dan kemokin, seperti TNF-a, IL-1, dan VEGF, yang selanjutnya mempengaruhi leukosit dan sel endotel untuk mengekspresikan faktor jaringan dan sejumlah molekul adesi lain yang mungkin sebagai predisposisi maupun memacu trombosis vena.

Peran trombosit. Sel tumor dapat mengakibatkan pengaktifan dan agregasi trombosit melalui interaksi langsung antar sel atau melalui mediator yang larut, termasuk ADP, trombin dan protease lain. Lebih lanjut, 
ekspresi sitokin tertentu oleh sel tumor, seperti TNF-a dan IL- $\beta$, menginduksi ekspresi faktor jaringan pada sel endotel dan serentak menurunkan ekspresi trombomodulin, yang mengakibatkan status protrombotik pada dinding pembuluh darah.

Terdapat bukti klinik luas dari berbagai studi adanya hubungan klinik dua arah antara kanker dan TEV, dimana kanker dapat memicu ekspresi aktifitas prokoagulan, yang mengakibatkan status protrombotik pada pasien, dan aktifitas prokoagulan sendiri dapat memicu sel kanker dalam hal pertumbuhan, proliferasi dan metastasis. Deposit fibrin dan trombosit di sekitar sel tumor padat memicu angiogenesis melalui faktor proangiogenik yang berasal dari trombosit, dan dapat "menyembunyikan" pembuluh darah tumor imatur sehingga melindungi sel kanker dari sistem imun. Telah dibuktikan juga bahwa fibrin dapat meningkatkan ekspresi faktor jaringan dan menginduksi ekspresi IL-8 dan VEGF yang dapat meningkatkan angiogenesis. ${ }^{17}$

Blokade secara eksperimental reseptor trombosit yang penting seperti GP1b/IX/V, GPIIb/IIIa dan GPVI mengakibatkan penurunan kolonisasi kanker paru, mengindikasikan adanya penurunan proses metastasis. Pemberian aspirin yang dikombinasikan dengan terapi bedah pada kanker paru jenis non-small cell dan kanker kolorektal dapat meningkatkan survival. ${ }^{18,19}$

Prokoagulan kanker. Sel tumor juga mengekspresikan prokoagulan kanker, suatu protease sistein yang hanya diekspresikan oleh jaringan kanker. Prokoagulan kanker langsung mengaktifkan faktor X dalam jalur bersama, tanpa tergantung faktor VII. Aktifitas protease ini dipengaruhi stadium kanker. Pada periode awal diagnosis kanker kadar protease biasanya tinggi, kemudian secara perlahan menurun. Kondisi ini dapat membantu menerangkan kecenderungan terjadinya tromboemboli pada 3 bulan pertama setelah diagnosis kanker. $^{20}$

Sel tumor selain mengekspresikan faktor jaringan dan prokoagulan kanker yang dapat meningkatkan status prokoagulasi, juga mengekspresikan protein yang mengatur sistem fibrinolitik, termasuk aktivator plasminogen, inhibitor aktivator plasminogen 1 dan 2, dan reseptor aktivator plasminogen, yang mengakibatkan gangguan keseimbangan mekanisme fibrinolisis. $^{21}$

\section{PENCEGAHAN TROMBOEMBOLI VENA PADA PENDERITA KANKER}

Dengan menggunakan model penentuan skor dari Khorana, seorang hematologis/onkologis dapat menggolongkan penderita kanker kedalam kelompok risiko TEV: rendah, menengah dan tinggi serta mempertimbangkan pemberian tromboprofilaksis untuk pasien.
Pencegahan trombosis pada penderita kanker yang menjalani operasi

Tindakan bedah pada penderita kanker akan meningkatkan risiko TEV dan pemberian pencegahan yang sesuai dapat menurunkan angka TEV secara bermakna. Sejumlah studi menunjukkan bahwa penderita kanker yang menjalani tindakan bedah mayor spesifik mempunyai insiden TEV pasca operasi dan risiko EP fatal 2-4 kali lipat lebih tinggi dibandingkan penderita tanpa kanker. Risiko untuk terjadi trombosis vena dalam yang dibuktikan secara venografi bervariasi mulai dari $20 \%$ hingga $40 \%$ dan risiko untuk terjadi emboli paru yang bersifat fatal sekitar $1 \%$. Oleh karena itu pencegahan rutin dengan menggunakan terapi antikoagulan sangat direkomendasikan pada kondisi segera setelah operasi dan periode yang diperpanjang setelah tindakan bedah mayor. $^{2}$

Obat yang digunakan sebagai terapi pencegahan secara luas adalah unfractionated heparin (UFH) dan heparin berat molekul rendah (LMWH). Tidak didapatkan perbedaan yang bermakna antara UFH dan LMWH dalam hal TEV simptomatik, perdarahan mayor, transfusi dan kematian. Studi ENOXACAN II telah melakukan penilaian efek terapi pencegahan yang diperpanjang (misalnya 21 hari) yang terbukti dapat mengurangi angka kejadian TVD dari $12 \%$ menjadi $4,8 \%$ $(p=0,02)^{22}$

\section{Pencegahan trombosis pada penderita kanker yang dirawat di rumah sakit atau tirah baring}

Oleh karena angka kejadian TEV pada penderita kanker yang dirawat di rumah sakit sangat tinggi, oleh sebab itu pemberian pencegahan primer dengan antikoagulan mungkin bermanfaat. Akan tetapi, manfaat tromboprofilaksis primer baik absolut maupun relatif bervariasi secara luas antara kelompok penderita akibat heterogenitas dari penderita kanker. Tromboprofilaksis kemungkinan sangat bermanfaat pada penderita yang didiagnosis awal sebagai kanker lanjut, khususnya yang merupakan kandidat kemoterapi. Juga penderita yang pada awalnya didiagnosa sebagai kanker stadium lokal atau regional yang mengalami progresifitas menjadi kanker yang bermetastasis atau bilamana mereka dirawat di rumah sakit dengan penyakit akut. Jadi, pasien selalu harus dipertimbangkan untuk pemberian pencegahan primer baik secara farmakologik maupun mekanik.

\section{Pencegahan trombosis pada penderita kanker rawat jalan}

Angka kejadian TEV simptomatik pasien rawat jalan dengan kanker lanjut atau kanker yang telah bermetastasis rendah (3\%). Pemberian pencegahan primer pada penderita kelompok ini dianggap tidak praktis dengan alasan: (i) angka kejadian TEV simptomatik pada pasien rawat jalan dengan kanker lanjut maupun kanker yang telah bermetastasis dianggap 


\section{TABEL 3}

Summary of antithrombotic guidelines for patients with cancer ${ }^{28}$

\begin{tabular}{|c|c|c|c|}
\hline Patient Group & Guideline & Recommendation & Agent \\
\hline Hospital inpatients & $\begin{array}{l}\text { ACCP, ASCO, } \\
\text { ESMO, NCCN }\end{array}$ & $\begin{array}{l}\text { In the absence of bleeding or other contraindications, } \\
\text { hospital inpatients should be considered candidates } \\
\text { for VTE prophylaxis }\end{array}$ & UFH, LMWH, FPX \\
\hline $\begin{array}{l}\text { Ambulatory patients } \\
\text { receiving } \\
\text { chemotherapy }\end{array}$ & $\begin{array}{l}\text { ASCO, ESMO, } \\
\text { NCCN }\end{array}$ & $\begin{array}{l}\text { Prophylaxis not generally recommended except for } \\
\text { patients at very high risk (those receiving thalidomide } \\
\text { or lenalidomide with chemotherapy) }\end{array}$ & $\begin{array}{l}\text { LMWH or adjusted-dose } \\
\text { warfarin }\end{array}$ \\
\hline $\begin{array}{l}\text { Patients scheduled to } \\
\text { undergo surgery }\end{array}$ & $\begin{array}{l}\text { ACCP, ASCO, } \\
\text { ESMO, NCCN }\end{array}$ & $\begin{array}{l}\text { Patients undergoing major surgical intervention } \\
\text { should be considered candidates for prioperative } \\
\text { prophylaxis }\end{array}$ & $\begin{array}{l}\text { Low dose UFH, LMWH } \\
\text { or FPX, consider long-term } \\
\text { LMWH for some patients }\end{array}$ \\
\hline $\begin{array}{l}\text { Patients with } \\
\text { established VTE }\end{array}$ & $\begin{array}{l}\text { ACCP,ASCO, } \\
\text { NCCN }\end{array}$ & $\begin{array}{l}\text { For patients with proximal DVT or pulmonary } \\
\text { embolism, extended prophylaxis with LMWH } \\
\text { (preferredoverwarfarin) is recommended }\end{array}$ & \\
\hline
\end{tabular}

ACCP, American College of Clinical Pharmacy; ASCO, American Society of Clinical Oncology; ESMO, European Society for Medical Oncology; NCCN, National Comprehensive Cancer Network; VTE, venous thromboembolism; UFH, unfractionated heparin; LMWH, low molecular weight heparin; FPX, fondaparinux; DVT, deep vein thrombosis.

rendah; (ii) risiko perdarahan menjadi permasalahan bagi penderita kanker; (iii) periode optimal untuk durasi profilaksis belum bisa ditentukan.

Penderita mieloma multipel yang mendapat terapi kombinasi dianggap termasuk kelompok risiko tinggi. Semua penderita mieloma baru yang mendapat terapi dengan regimen yang mengandung thalidomide atau lenalidomide sebaiknya diberikan terapi pencegahan trombosis.

\section{Pengaruh trombosis pada penderita kanker}
a. Angka mortalitas tinggi
b. Risiko perdarahan lebih tinggi
c. Biaya pengobatan tinggi
d. Angka kekambuhan TEV tinggi
e. Post-thrombotic syndrome
f. Hipertensi pulmonal

\section{TERAPI TEV PADA PENDERITA KANKER}

Terdapat beberapa studi tentang terapi TEV pada penderita kanker. Studi CLOT (Comparison of Lowmolecular-weight heparin versus Oral anticoagulant Therapy for the prevention of recurrent venous thromboembolism in patient with cancer), merupakan studi besar dengan melibatkan sebanyak 672 pasien, yang membandingkan antara terapi dengan dalteparin dan antagonis vitamin K. Studi ini melaporkan adanya penurunan risiko (RRR) sebesar 52\% untuk kejadian TEV pada kelompok dalteparin selama periode studi 6 bulan. ${ }^{23}$ Atas dasar bukti klinik yang ada, ASCO dan NCCN merekomendasikan penggunaan LMWH minimal selama 6 bulan sebagai terapi baku dalam penatalaksanan TEV pada kanker. Masalah jangka waktu yang optimal untuk pemberian antikoagulan pada penderita kanker dengan TEV masih belum dapat didefinisikan, penderita ini tetap mempunyai risiko TEV sepanjang kanker masih aktif. Panduan ini merekomendasikan bahwa penderita dengan kanker aktif dipertimbangkan untuk pemberian antikoagulan dalam waktu yang tak terbatas, namun keputusan harus didasarkan atas evaluasi yang cermat dari rasio antara manfaat dan risiko. ${ }^{24,25}$

Penggunaan obat generasi baru seperti inhibitor trombin maupun inhibitor faktor Xa (direct thrombin inhibitor dan direct Xa inhibitor), seperti dabigatran dan rivaroxaban, menunjukkan bahwa kedua obat tersebut sebanding dengan warfarin dalam hal efektifitas dan keamanan, namun baru sedikit penderita kanker yang terlibat dalam studi ini. ${ }^{26}$ Hasil studi lanjutan yang mengamati efektifitas rivaroxaban sebagai pencegahan sekunder menunjukkan, bahwa rivaroxaban memberikan penurunan secara bermakna $(1,3 \%$ vs $7,1 \%)$ untuk risiko kejadian TEV berulang pada penderita yang dapat menyelesaikan jadwal terapi antikoagulan yang diberikan. ${ }^{27}$ Obat baru ini cukup menarik sebab pemberian secara oral dan tidak memerlukan pemantauan laboratorium, namun efektifitas dan keamanan pada penderita kanker perlu diteliti secara menyeluruh. 


\section{PENUTUP}

Tromboemboli vena merupakan komplikasi yang sering terjadi pada penderita kanker dan merupakan penyebab kematian penting bagi penderita kanker. Obat antikoagulan yang ada saat ini cukup efektif dan relatif aman untuk pencegahan maupun terapi trombosis pada kanker, namun tidak nyaman bagi penderita. Obat baru seperti penghambat trombin langsung maupun penghambat F. Xa langsung (dabigatran, rivaroxaban) nampaknya menjanjikan; namun perlu lebih banyak lagi data pada populasi penderita kanker.

Pemahaman patofisiologi trombosis pada kanker dan pengaruh terhadap biologi tumor amat penting guna mengidentifikasi penderita dengan risiko tinggi yang sangat bermanfaat apabila diberikan obat antikoagulan sebagai pencegahan primer.

\section{DAFTAR PUSTAKA}

1. Shelke AR, Khorana AA. Cancer-associated thrombosis: an update. Drug discovery today: disease mechanisms. Hematology 2011;8:e39-e45.

2. Zaher GF, Abdelaal A. Venous thromboembolism in cancer. In: Abdeaal A. Pathophysiology and clinical aspects of venous thromboembolism in neonates, renal disease and cancer patients. Croatia. Intech. Croatia. 2012:73-114.

3. Silverstein MD, Heit JA, Mohr DN, Petterson TM, O'Fallon WM, Melton III LJ. Trend in the incidence of deep vein thrombosis and pulmonary embolism: a 25-year populationbased study. Arc Int med 1998;158(6):585-93.

4. Sallah S, Wan Jy, Nguyen NP. Venous thromboembolisme in patients with solid tumors: determinations on frequency and characteristics. Thromb Haemost 2002;87(4):575-9.

5. Stein PD, Beemath A, Meyers FA, Skaf E, Sanchez J, Olson RE. Incidence of venous thromboembolisms in patients hospitalized with cancer. Am J Med 2006;119 (1):60-8.

6. Lee AY, Levine MN. Venous thromboembolism and cancer. Risks and outcomes. Circulation 2003;107(23 Suppl1):117-21.

7. Prandoni P, Lensing AW, Piccioli A, Bernardi E, Simioni P,Girolami B, et al. Recurrent venous thromboembolism and bleeding complications during anticoagulant treatment in patient with cancer and venous thrombosis. Blood 2002;100:3484-8.

8. Chew HK, Wun T, Harvey DJ, Zhou H, White RH. Incidence of venous thromboembolism and the impact on survival in breast cancer patients. J Clin Oncol 2007;25:70-76.

9. Khorana, AA et al. Frequency, risk factors, and trends for venous thromboembolism among hospitalized cancer patients. Cancer 2007;110:2339-2346.

10. Blom JW, Osanto S, et al. Malignancies, prothrombotic mutations, and the risk of venous thrombosis. JAMA 2005; ;293:715-722.
11. Khorana AA, Kuderer NM, Culakova E, Lyman GH, Francis CW. Development and validation of a predictive model for chemotherapy associated thrombosis. Blood 2008;111(10):4902-4907).

12. Gale AJ, et al. Update on tumor cell procoagulant factors. Acta Haematol 2001;106:25-32.

13. Mackman N. Role of tissue factor in hemostasis, thrombosis, and vascular development. Arterioscler Thromb Vasc Biol 2004;24:1015-1022.

14. Khorana AA, Francis CW, Cuakova E, et al. Tissue factor expression, angiogenesis, and thrombosis in pancreatic cancer. Clin Cancer Res 2007;13:2870-2875.

15. Kakkar AK, DeRuvo N. Chinswangwatanakul V, Tebbutt S, Williamson RC. Extrinsic pathway activation in cancer with high factor VIIa and tissue factor. Lancet 1995;346:1004-1005.

16. Rickles FR. Brenner B. Tissue factor and cancer. Semin Thromb Hemost 2008;34:143-145.

17. Fernandez PM, Patierno SR, Rickles FR. Tissue factor and fibrin in tumor angiogenesis. Semin Thromb Hemost 2004;30:31-44.

18. Fontaine E, et al. Aspirin and non-small cell lung cancer resections: effect on longterm survival. Eur JP Cardiothorac Surg 2010;38:21-26.

19. Rothwel PM et al. Long term effect of aspirin on colorectal cancer incidence and mortality:20-year follow-up of five randomized trials. Lancet2010;376:1741-1750.

20. Mielicki WP, Tenderenda M, Rutkowski P, Chojnowski K. Activation of blood coagulation and the activity of cancer procoagulant (EC3.4.22.26) in breast cancer patients. Cancer Lett 1999;146:61-66.

21. Prandoni P, Villalta S, Bagatella P, Rossi L, Marchiori A, Piccoli $\mathrm{A}$, et al. The clinical course of deep vein thrombosis. Porspective long-term follow up of 528 symptomatic patients. Haematologica 1997b)82:423-428.

22. A double-blind randomized multicenter trial with venographic assessment. ENOXACAN study group. Br.J Surg 1997;84(8):1099-103.

23. Lee AY, et al. Low-molecular-weight heparin versus a coumarin for the prevention of recurrent venous thromboembolism in patients with cancer. Cochrane database syst.Rev.2011;4. Cdoo6649.

24. Lyman GH, et al. American Society Clinical Oncology guidline: recommendations for venous thromboembolism prophylaxis and treatment in patients with cancer. J. Clin.Oncol. 2007; 25: 5490-5505.

25. Wagman LD, et al. Venous thromboembolic disease. NCCN clinical practice guidelines in oncology. J. Natl. Compr. Canc. Netw. 2008;6:716-753.

26. Schulman S, et al. Dabigatran versus warfarin in the treatment of acute venous thromboembolism. N. Engl. J. Med. 2009;361:2342-2352.

27. Bauersach $\mathrm{R}$, et al. Oral rivaroxaban for symptomatic venous thromboembolism. N. Engl. J. Med. 2010;23:2499-2510.

28. Semchuk WM, Sperlich C. Prevention and treatment of venousthromboembolism in patients with cancer.CPJ/RPC 2012;145:24-29. 